\title{
Provisions on Arbitration Proceedings Set Down in Cartel Agreements Based on the First Hungarian Cartel Act
}

\author{
By Norbert Varga*
}

\begin{abstract}
The characteristics of the twentieth century cartel movement deemed it contradictory to free trade, because the measures that limited fair trade were the direct results of free trade itself, and thus the only way to oppose it and protect the consumers' interests was to guarantee free competition, i.e. the fundamental enforcement of public well-being, public economy and public morals. In this study, I wish to describe the regulations that address the stipulations of arbitration courts by analysing archival sources. Specifically, this paper will examine the role arbitration courts played during dispute settlements between concerned parties before the first Cartel Act of Hungary came into effect in 1931.
\end{abstract}

Keywords: Cartel; Arbitration process; Juries and arbitral tribunals; Hungary

\section{Introduction}

Procedural rules pertaining to cartels were significant among the arbitration requirements laid down in cartel agreements. Pursuant to these rules, the parties to an agreement determined how and within what framework any potential disputes would be decided. In the case of rules on the arbitral tribunal, we need to review the relevant provisions of Act I of 1911. By analysing individual cartel agreements, we will also gain insight into the terms and conditions under which parties to various cartel agreements wished to set up their respective tribunals to deal with problem cases, and the manner in which they attempted to pre-empt court proceedings. ${ }^{1}$

\section{Procedural Rules of the Arbitration}

One unique feature of the arbitration proceedings was that they were based upon an agreement entered into by the parties. The raison d'être of these proceedings was the principle of disposal; the proceedings were thus a consequence

\footnotetext{
*Ph.D. (History); Ph.D. (Law and Political sciences). Associate professor, Department of Hunharian Legal History, Faculty of Law and Political Sciences, Univerfsity of Szeged, Szeged, Hungary. Email:vargan@juris.u-szeged.hu.

${ }^{1}$ Supported by János Bolyai Research Scholarship (BO/00198/18/9). A Budapesti Kereskedelmi és Iparkamara mellett müködő zsürik és választott bíróságok müködése [The functioning of the juries and arbitral tribunals operating in conjunction with the Budapest Chamber of Commerce and Industry]. Ujság, 12 and 14 February 1930; on antecedents to civil procedure law, see Meszlény (1911) at 393-402.
} 
of this principle. A precondition of the proceedings was that an arbitration agreement or an agreement with pertinent provisions had been made between the parties. This agreement was only valid if it was in writing and pertained to a specified case or a dispute arising out of a legal relationship. While the parties were free to agree on the scope of the agreement, this meant that the arbitral tribunal could not proceed in every matter, even if the parties had the right of disposal over that matter. ${ }^{2}$

First, a decision had to be made regarding the identity of the arbitrators. The parties could agree on the arbitrators or designate them in the agreement. If there was no clause addressing this subject in the agreement, each party could select an arbitrator, or they could select arbitrators jointly. However, if they could not agree on the identity of the arbitrators, then the matter was decided by majority vote. In the event of a tied vote, they would draw straws to decide who the arbitrators might be. In addition to an indication of each arbitrator's occupation and address, their choice of arbitrators had to be put in writing, as well as indicating whether the persons chosen as arbitrators had accepted the office. When arbitration was to be implemented, one party could call on the opposing party to exercise the right of choice, for which that party had a period of fifteen days. The identity of the arbitrator had to be communicated to the opposing party by a notary public or the district court.

In the event that an arbitrator could not fill the office for some reason (e.g. death or unwillingness to participate in the proceedings), the party could then exercise the right of choice again. If the party waived this right, they could then withdraw from the arbitration agreement or request that an arbitrator be appointed by a court. In the latter case, the court would decide without hearing from that party. ${ }^{3}$ For the subject under discussion in this paper, the term court should be understood to mean "a court of justice which would have had jurisdiction and competence in the absence of an arbitration agreement." This court could order enforcement based on the judgement or pact. If several courts were competent in the matter, the court to which one of the parties or the tribunal had turned was the one that proceeded with the case. ${ }^{4}$

Once the person selected as arbitrator agreed to the appointment, he had to declare in writing that he had undertaken this duty. This declaration thus qualified as a contract between the parties and the arbitrator. After having been selected, if the arbitrator failed to perform his duty without due cause or did not fulfil his duty in a timely fashion, either party could then submit a petition to the court requesting that the arbitrator be fined. An appeal could be lodged against the decision, and the incurred costs and damages had to be paid. ${ }^{5}$

The grounds for excluding judges were germane for arbitrators as well. In addition to the applicable general rules, the following groups were excluded: women, minors, persons in care or undergoing bankruptcy proceedings, and the

\footnotetext{
${ }^{2}$ Bacsó (1917) at 323.

${ }^{3}$ Kamarai választott bíróság bírája nem kamara köteles perében [An arbitrator on the chamber's arbitral tribunal in a trial not required by the chamber]. Közgazdasági Értesitö (30), 1935/8, at 2.

${ }^{4}$ Gaár (1911) at 385-411; Bacsó (1917) at 328; Magyary (n.d.) at 736-737.

${ }^{5}$ Bacsó (1917) at 324-325; Magyary, (n.d.) at 733-735; Falcsik, (1908) at 376-377.
} 
blind, deaf and mute, as well as persons who had lost office or were suspended from exercising their political rights as an ancillary penalty. The court would decide on the petition for exclusion in an oral hearing after hearing the arbitrator in question, if necessary, and the court's decision could be appealed.

The arbitration agreement ceased to take effect in the following cases: if any of the arbitrators specified in the agreement failed to undertake the arbitration proceedings, died, could not engage in the arbitration proceedings for some reason, or refused to fulfil their duty.

The parties themselves set down the type of proceedings to be used. They could appoint counsel to represent them, and jointly determine the remuneration made to members of the arbitral tribunal. If they could not make that determination, the tribunal then decided on the matter, and decisions on this matter could be appealed at the court that would have acted as a court of appeal in the absence of an arbitration agreement. The tribunal could hear witnesses and experts, but could not have trial participants and parties swear an oath. In the event that the tribunal was expected to engage in trial proceedings or actions for which it had no powers, the competent district court was to be approached.

Arbitration proceedings could not be stopped by a claim made by any of the parties that the arbitration agreement was invalid, that it did not cover the matter to be decided, or that one of the members of the tribunal could not proceed on the matter, provided that a binding court decision had not been handed down following a review of these disputes. If the tribunal was delayed in making a judgement, either party could request that the court set a deadline. If the deadline was missed, the arbitration agreement expired for that particular matter. In this case, the court decided after hearing the members of the tribunal. If the tribunal was comprised of more than two members, decisions were taken by a majority voice vote, each and every member confirming its judgement with their signature. While the parties could enter into a pact with one another during the proceedings, the judgement or the pact also had to be forwarded to the competent court.

Once a judgement was passed down by an arbitral tribunal, redress by trial was not an option. The judgement could only be invalidated by lodging a petition with a court in the following cases: (a) if there was no arbitration agreement, if such an agreement was not valid, if it did not pertain to the matter in question and if it expired before the judgement was made, even if the rules on the formation of the tribunal or its adjudication were infringed; (b) if a person who had been excluded by a court took part in the adjudication; (c) if a party was not given a hearing during the proceedings; (e) if rules governing the judgement signing were not observed; ( $f$ ) if a judgement obliged a party to take illegal action or if the section that provided for this was incomprehensible; and, finally, $(\mathrm{g})$ even if there were grounds for a retrial pursuant to the Act on civil procedure, Sec. 563(5-9).

A pact entered into before an arbitral tribunal could be challenged with a petition before a court. An annulment case could be initiated within 90 days after a judgement was passed down by the tribunal. Once the proceedings were initiated, the court could then suspend the execution of the judgment by the tribunal, even 
without hearing the party. The court could also withdraw its own decision to suspend the execution of the tribunal's judgement. ${ }^{6}$

\section{Bakers Protection Pact}

Next, I wish to describe arbitration rules in practice, based on archival sources on cartels. Among the Cartel Committee's materials is the Bakers Protection Pact, containing the provision on arbitration proceedings described below.

Decisions on any disputes and judgement on any claims arising from the legal relationship regulated by the pact were left to the arbitral tribunal. Adjudicating appeals that were referred to the competence of the tribunal in the pact also fell within the jurisdiction of the tribunal.

The pact included information on the composition of the arbitral tribunal, as follows: The president of the tribunal, Adolf Trutzl, was permanent, and his copresidents were Béla Neumann, Ferenc Holndonner Jr, Gyula Czittler and Sándor Fürst. If the president was indisposed, the first co-president appointed acted in his place. If he was also indisposed, the person who was next in line filled the office of president. If either the president or one of the co-presidents of the tribunal could not undertake this office, then the meeting of members chose their replacement.

The parties set down the following general rules on the proceedings before the arbitral tribunal. For example, if a person wished to lodge some dispute or other claim before the tribunal, the relevant petition, action or appeal was to be submitted to the tribunal. The president of the arbitral tribunal himself undertook the presidency of the tribunal to be formed for a particular case or designated one of his co-presidents as president. If there were no grounds for exclusion against the president or if the president-to-be or co-presidents were indisposed, the president and the co-presidents of the new tribunal set in place to hear the particular case would be appointed by the president of the arbitral tribunal. However, failure to maintain this sequence was not grounds for challenging the legality of the formation of the tribunal.

The president or appointed president notified the claimant and the respondent in writing without delay that they should designate their own arbitrators within 48 hours of the notification and that the arbitrators' statements accepting this appointment should be simultaneously attached. The parties could only designate a member of the pact or a representative as an arbitrator. If one of the parties did not designate an arbitrator by the set deadline or did not attach a statement of acceptance, or if the designated arbitrator withdrew, the arbitrator was then appointed by the president of the tribunal. Members of the board of directors could not be presidents or members of the tribunal. Persons who were members of a committee against which an action or appeal was directed, or that officially dealt with the matter at issue in the case, could not act as arbitrators. Persons involved in an investigative or auditory action were also excluded from the proceedings. An arbitrator was also prohibited from taking on this role if any party raised serious doubts as to that person's impartiality.

${ }^{6}$ Bacsó (1917) at 326-328; Zoltán, (1986) at 472; Dobrovics (1933) at 14. 
In the event that an appeal had been lodged against a decision in a case involving opposing parties, the arbitrator could then only be designated by these opposing parties. If there were more than two opposing parties, each of them could appoint an arbitrator. Several parties on the same side could designate an arbitrator jointly. If parties on the same side could not agree, the president of the tribunal designated their arbitrator.

The arbitral tribunal proceeded with the case in a hearing, where it presented its statements and was free to set the manner of the proceedings. Evidentiary material registered by the audit committee or the consumer protection committee could be used and supplemented by the arbitral tribunal, and it could order that evidence be presented again. A judgement by the tribunal had to be justified, and delivered to the director of legal affairs at the Hungarian Royal Treasury, with a waiting period of at least fifteen days before it could be executed. The tribunal could require the losing party to pay its costs, and appealing against a judgement by the tribunal was not possible.

\section{Sugar Cartel}

The Alföld Sugar Company materials contain a draft cartel agreement from 1942, which likewise regulated the arbitral tribunal. According to the draft agreement, the firms signed on to the agreement consented to the exclusive power and competence of a three-member tribunal regulated by Act 1 of 1911, Title XVIII, to decide all disputes and matters of litigation arising from the cartel agreement, with the exception of specific matters expressly referred to another forum. The tribunal could also decide on the validity of the arbitration agreement.

One member of the arbitral tribunal was selected by the party acting as the claimant or, if several parties took part, the selection was made jointly. The same process was undertaken by the respondent party. Both parties declared that the "tribunal will not merely explain the operation of established law. It will also be authorised to take constitutive decisions on all questions rendered necessary by the inadequacy of the present agreement or for other important reasons. That is, the tribunal will also be authorised to issue judgements regarding the legal relations between the parties to the agreement, which remain valid until such time as the cartel is terminated and which could otherwise only be established based on a statement of will on the part of the parties to the agreement." 8

The third member of the arbitral tribunal was the president, agreed upon by the arbitrators. If the parties were unable to agree on a third member of the tribunal within fifteen days, the president of the tribunal was then appointed by the chairman of the board of the Budapest Stock and Commodities Exchange. ${ }^{9}$ If the

\footnotetext{
${ }^{7}$ Cartel committee materials: MNL. K-148. 1934. 41. tétel. 28720. alapszám, 71729. [National Archives of Hungary. Lot K-148. 1934. 41 No. 28720, 71729]; Szentpáli (1933) at 16.

${ }^{8}$ MNL. (Gazdasági Levéltár) 256-V. 181. tétel 56. csomó. [National Archives of Hungary (Business Archives). Lot 256-V. 181 Batch 56.]

${ }^{9}$ Fifteen points in the Austro-Hungarian iron cartel agreement refer disputes to the arbitral tribunal for the Budapest Stock and Commodities Exchange. MNL. (Gazdasági Levéltár). Osztrák-Magyar Vas- és acélkartell Z 372. 43-44. tétel. A tőzsdebíróságról, mint választott bíróság szabályozásáról.
} 
president of the tribunal could not fulfil his duties, the vice-president would then proceed to act.

If it was established during the arbitration proceedings that one of the parties' actions or failure to act was in breach of an essential provision of the agreement or was "contrary to the spirit of the cartel", the relevant person could then be issued a fine of 100,000 gold pengős on a case-by-case basis. A performance obligation and compensation could also be ordered in addition to the payment of the fine, which had to be divided between the parties in proportion to the size of their participation. A fine could be imposed several times, if necessary. The sugar companies also agreed that, except in cases of termination, the cartel had to be maintained. "In this regard, the parties shall grant the most far-reaching powers to the arbitral tribunal, supported by the principle that the tribunal, by the shared will of the parties, shall first and foremost bear in mind the continued validity and inviolability of the cartel and the obligation to compel all the contracting parties to adhere to the present agreement."10

\section{Sodium Silicate Cartel}

Among the material found at Viktória Chemical Works is a cartel agreement that regulates the structure and proceedings of the arbitral tribunal. This agreement stands out because the parties set down detailed rules regarding the tribunal in a separate arbitration agreement.

The parties to the cartel agreement (Drucker Dezső Pallas Chemical Plant, United Light Bulb and Electric Company, Dr Helvey Tivadar Chemical Plant, Rosenberg Miklós Chemical Plant, Rudas Ernö Concordia Chemical Company, Soroksár First Sand Lime Brick Company and Viktória Chemical Works) stipulated that they recognise and agree that "in excluding the court, [we] submit to the exclusive competence and unappealable judgement of a three-member arbitral tribunal"11 to settle all disputes arising from the agreement and adjudicate and collect all claims. The tribunal was assembled in cases of dispute pertaining to escrow agreements and in adjudicating and collecting related claims. ${ }^{12}$

The cartel agreement entered into by the firms listed above decreed that the parties and the Hungarian Industry and Trade Monitoring Bank had entered into an agreement regarding the exclusive sale of sodium silicate on commission as well as on providing control and escrow services, based on which the bank undertook an order to make such sales on commission and to provide such control and escrow services. The bank's powers included deciding disputes arising from or

[National Archives of Hungary (Business Archives). Austro-Hungarian iron and steel cartel. Lots Z 372. 43-44. On regulating the stock exchange tribunal as an arbitral tribunal.] Róth (1901) at 200 202.

${ }^{10}$ MNL. (Gazdasági Levéltár) 256-V. 181. tétel 56. csomó. [National Archives of Hungary (Business Archives). Lot 256-V. 181 Batch 56.]

${ }^{11}$ MNL.(Gazdasági Levéltár) Viktória Vegyészeti Mủvek Rt. Z 341 Ügyvezetői-igazgatóság iratai 2. raktári szám, Kartell ügyek. [National Archives of Hungary (Business Archives). Viktória Chemical Works. Z 341. Managing director's documents, Stock No. 2, Cartel cases.]

${ }^{12}$ Ibid. 
pertaining to legal relations, especially compensation claims, and to setting fines. The parties to the agreement likewise left the decision to the arbitral tribunal to appeal decisions taken at cartel sessions regulated in the cartel agreement. In this case, the tribunal was comprised of three members. The claimant or claimants before the tribunal notified the respondent by registered mail, while simultaneously designating the arbitrator on the tribunal and forwarding the statement of acceptance from the arbitrator. The respondent had to designate their choice for the arbitration tribunal within eight days of receiving the notification and send a statement of acceptance by registered mail. In the event that several parties entered the lawsuit on the side of the claimant or the respondent, an arbitrator could then be selected by a simple voice majority. The president would be jointly selected by the two arbitrators appointed by the claimant(s) and respondents(s). If the respondent did not designate an arbitrator within eight days or if no agreement could be reached regarding the identity of the tribunal president, these decisions would be made by the president of the National Association of Hungarian Industrialists or, if he was indisposed, by his deputy.

A judgement by the arbitral tribunal had to be justified, and no appeal could be lodged against this judgement. Provisions of Act XX of 1931 had to be observed during the arbitration proceedings, with the judgement to be delivered to the director of legal affairs at the Hungarian Royal Treasury. The claimant had to place the sum of the costs set by the tribunal on deposit. The provisions of the Act on Civil Procedure were to be applied to the formation of the tribunal and the arbitration proceedings, provided that the parties had not regulated these areas in the agreement. ${ }^{13}$

\section{Ice Cartel}

Not every cartel agreement contained an arbitration clause. The Budapest Ice Sales Company and the Huszár József István Ice Company, situated in what was then the separate town of Újpest, entered into an agreement to regulate the ice trade in Budapest, Újpest and Rákospalota, wishing to lay down a unified and joint regulation in the agreement. They specified the terms of ice distribution, the maximum distribution amount and the fine to be paid in the case of overproduction, and dictated the prices and procedure that was to be followed against resellers. They also set down that any disputes arising from the agreement should be settled by the Budapest Central Royal District Court or the Budapest Royal Court of Justice, depending on the court's jurisdiction based upon the value of the lawsuit. ${ }^{14}$

It becomes clear from the provisions on the arbitral tribunal that the structure was regulated in an essentially identical manner. The parties wished first and foremost to settle legal disputes among themselves. This is why they attempted to lay down the rules of procedure in the cartel agreements in as much detail as

\footnotetext{
${ }^{13}$ Ibid.

${ }^{14}$ NL Budapest Főváros Levéltára XI. 1105 1. kisdoboz 1 Kartell jegyzökönyvek, megállapodások 1927-1943 [Budapest City Archives, National Archives of Hungary, Folder XI. 1105 1, Cartel minutes of meetings and agreements 1927-1943].
} 
possible, with an eye to Act I of 1911 on the civil trial process as a background law.

A judgement passed down by the arbitral tribunal could only be overturned by the Cartel Court. ${ }^{15}$ For this reason, the manner in which the effect of the judgements by the tribunal was regulated was particularly significant. "There would be no purpose for the provisions of the Act on cartels if one could manage to enforce judgements by ignoring the intention of the Act on cartels and stipulating involvement by the arbitral tribunal." 16

The Cartel Court had jurisdiction over lawsuits of public interest, impositions of temporary measures, impositions of fines as penalty, disqualification, the annulment of any arbitration award and the suspension of the execution of any arbitration decision. ${ }^{17}$ This Court could only order the dissolution of a cartel and prohibit its further operation if the cartel had engaged in conduct that was detrimental to the public interest and if that conduct could not otherwise be terminated.

The Act gave the minister the right to request the dissolution directly from the court without recourse to other means. However, exercising the rights of dissolution could also constitute a restriction of fundamental rights. Specifically, it could restrict the exercise of the freedom of association. Yet, constitutional rights could only be restricted by way of exception and only if the act was authorized by a statute. In any other case, the judicial measure would have been unlawful, as it would have been determined by an arbitrary exercise of law.

With the dissolution of the cartel, the court usually prohibited the cartel and its members from continuing to operate. The dissolution of the cartel did not preclude the members from keeping up the cartel's operation by acting in unison. This meant that the sentence could only be enforced if the court also prohibited the cartel from operating.

It was possible for a cartel that had been dissolved, to later be re-established. This was not explicitly prohibited by the law, and so, in practice, the court's decision concerned only the dissolution and prohibition of the operation of the cartel involved in the action. The new cartel, if it was formed as the result of a new agreement, was not covered by the previous decision. New legal action had to be initiated against the operation of the new cartel, and new evidence was needed to demonstrate that its operation was against the public interest. However, in urgent cases, the minister could consider taking provisional measures.

If the abuse committed by the cartel could be terminated by enforcing an agreement or a decision, then the court ordered the enforcement of the relevant agreement or decision. A similar decision was taken when the claim was filed for the dissolution of the cartel. On the other hand, if a claim was made for the prohibition of an agreement or a decision, the court could not pronounce the

\footnotetext{
${ }^{15}$ A kartelbíróság első ügye [The first case before the Cartel Court]. A kartel (2), 1933/4, at 31. A Kartelbíróság megsemmisít egy választott bírósági ítéletet [The Cartel Court annuls a judgement by an arbitral tribunal]. A kartel (2), 1933/5, at 39-40. Ranschburg (1931) at 119-124; Magyary (n.d.) at 743-744; Kovács (1930) at 1700; Szabó (2016) at 79.

${ }^{16}$ Kelemen (1933) at 17.

${ }^{17}$ Harasztosi (1936) at 546-547. See more on this topic: A Kartelbíróság újabb ítélete. [The Cartel Court's new ruling], A Kartel [The Cartel] (3) 1933/1. at 8.
} 
dissolution of the cartel in its ruling. Otherwise, the court would have gone beyond the scope of the claim, which would have been incompatible with Act I. of 1911 on the Code of Civil Procedure. The termination of the operations or the conduct of the cartel was only requested if the cartel's conduct could not be demonstrably linked to an agreement.

In the following case, legal action was brought to the Cartel Court because of the invalidity of the cartel contract and of the arbitration clause contained therein, and because of a failure to present the cartel contract to the minister. The contract, including an arbitration clause, established commitments regarding goods in a manner that restricted competition in terms of turnover and price formation; therefore, it fell within Sections 1 and 2 of Act XX of 1931. Commercial associations also participated in the formation of the agreement, which, according to the Cartel Act, had to be recorded in writing and presented to the responsible minister in office for registration. The presentation was regulated by special rules, because the contract in question had been drawn up before the Cartel Act came into effect (October 15, 1931); therefore, according to Section 16 of the Cartel Act, its presentation should have been performed within 45 days after it came into effect, namely until November $29,1931 .{ }^{18}$

The Cartel Court found that the presentation had not taken place, and for this reason, pursuant to Section 2 of the Cartel Act, the agreement was annulled, and the arbitration clause included therein, "as an additional part of ancillary nature of the main agreement, sharing the fate of the main agreement, also became invalidated; therefore, the arbitral tribunal that gathered on the $9^{\text {th }}$ of February in the year 1932 based on this invalidated contract could not have been instituted in a legal sense." 19

Enforcing the performance of obligations based on invalid agreements through decisions of arbitral tribunals was unquestionably against the law; as a result, the legal directorate of the Treasury, acting upon the order of the minister, could ask for the invalidation of the decision of the arbitral tribunal pursuant to Section 13 of the Cartel Act. The co-defendant's reasoning that the claim in question would fall under the jurisdiction of an ordinary court instead of the Cartel Court was unfounded because Section 2 of Section 13 of the Cartel Act stated that the legal claim could be filed at the Cartel Court exclusively. Based on the aforementioned grounds, the Cartel Court dismissed the judgement of the arbitral tribunal.

In another case, the Cartel Court reached a similar decision when, due to the failure to present the agreement, the arbitration clause, which formed part of the annulled agreement, "sharing the fate of the main agreement, also became invalidated." ${ }^{20}$ The Cartel Court declared that the Cartel Act did not contain any

\footnotetext{
${ }^{18}$ A kartelltörvény hatálybaléptetésről szóló 5381/1931. M. E. rendelet. [Prime Minister Decree 5381 of 1931 on The Enforcement of the Cartel Act. P. IV.] 3013/1932. In: Nizsalovszky, Petrovay, Térfy, Zehery, (1931-1932) at 577.

${ }^{19}$ P. IV. 3013/1932. In: GDt. vol. XXV, at 577.

${ }^{20}$ P. IV. 5261/1932. GDt. vol. XXVI, at 740-741. In the same decision, the Cartel Court also stated that an action of public interest can be brought "even if public interests are not threatened but one of the other criteria set out in the Act is violated.” Egy elvi jelentőségü itélet, [A Principled Decision] Pesti Napló, 18 August 1932, at 7.
} 
provisions that would have allowed the minister to decide on appeals attempting to justify the failure to present the required documents.

In the case at hand, the co-defendants of the second and third degrees concluded an agreement on December 28, 1928, and January 1, 1929, for the period between January 1, 1929, and January 30, 1932. The agreement contained mutually binding provisions regulating the acquisition of firewood, coal, coke and smithy coal; their sale in and around the town of P. (Pápa), the determination of sales prices and sales conditions of products, the handling of the turnover of goods and the related accounting, and mutual customer protection. The aim of this agreement between the co-defendants of the second and third degrees was to determine the actions of the parties for a longer period of time, rather than to regulate the occasional conduct of their transactions. The obvious purpose of the mutual commitments included in the agreement was to regulate economic competition in terms of the said products in connection to turnover and price formation. In its decision, the Cartel Court ruled that "such an agreement, regardless of its personal, economic or geographical scope, falls within Section 1 of the $20^{\text {th }}$ Act of $1931 .{ }^{, 21}$ Some commercial associations were contracting parties of the agreement; therefore, because of the reasons set out in the aforementioned case, the agreement should have been presented to the minister, but this had never happened. The agreement was set aside pursuant to Section 2 of the Cartel Act, and it was not altered by the fact that, after the invitation of the minister, the secondary co-defendant fulfilled its obligation to present the agreement on September 1, 1932. "For a case that was invalidated due to the failure to adhere to a legally pre-established deadline, cannot be made valid again by belated compliance." 22

The arguments of the defence claiming that the validity and scope of the arbitration clause did not necessarily coincide with those of the main contract were also deemed invalid, 'because the 'public interest' nature and the special (law enforcement) nature of the regulation of the legal relationship under discussion, and also, the purpose of the adoption of Act 20 of 1931 warrant equal evaluation of the substantive law and the procedural law effect of the cartel agreement." 23

In this case, too, the arbitration clause of the agreement was invalidated after the deadline for presentation had passed, therefore, based on the invalidated clause, the arbitral tribunal could not have been formed legally. As a result, the arbitral tribunal could not even have reached a conclusion that affected the rights and commitments of the parties originating in the period of time when the cartel agreement was (lawfully) in effect. The Cartel Court held that "both those provisions of the main agreement that are closely linked to each other and the 'inseverable amendments' [...] added later constitute a unified, single legislative act (document), which has no clauses that could be valid on their own, without a (cartel) agreement drafted in accordance with Section 1 of Act XX of the year

\footnotetext{
${ }^{21}$ A szénkartel vesszöfutása a kartelbíróság elött, [The Ordeal of the Coal Cartel in Front of the Cartel Court] Pesti Napló, 21 December 1932, p. 6. Köházi (1934) at 8-9.

${ }^{22}$ The Cartel Court quoted the following case: P. IV. 3013/1932. In: P. IV. 5261/1932. GDt. Vol. XXVI. pp. 740-741.

${ }^{23}$ P. IV 5261/1932. In: GDt. vol. XXVI, p. 741.
} 
1931. As a result, although the defendant argued that, under Section 11 of the Act, the arbitral tribunal had legal rights to adjudicate [...] on claims that were related to the contract and that could be judged as valid despite the fact that the cartel agreement itself was invalidated, this argument was declared to be without merit." ${ }^{24}$ Based on all of these, the Cartel Court dismissed the judgement of the arbitral tribunal.

\section{Conclusions}

Act XX of 1931 considered the assertion of the public interest key in judgements by the arbitral tribunal. In the event that one of the parties protested the cartel agreement as being contrary to the public interest during a proceeding, the tribunal then had to suspend the proceedings and transfer the matter to the competent minister. In the event of a breach of the public interest, at the minister's request and with a petition from the director of legal affairs, a public interest trial could be initiated, which then terminated the arbitration proceedings. ${ }^{25}$ The protection of the public interest against private interests was powerfully asserted through the cartel agreements. This kind of intervention in private law on the part of the state stemmed from the altered economic conditions of the twentieth century.

\section{References}

A Budapesti Kereskedelmi és Iparkamara mellett működő zsűrik és választott bíróságok müködése [The functioning of the juries and arbitral tribunals operating in conjunction with the Budapest Chamber of Commerce and Industry]. Ujság, 12 and 14 February 1930.

A kartelbíróság első ügye [The first case before the Cartel Court]. A kartel, 1933, 2:4.

A Kartelbíróság megsemmisít egy választott bírósági ítéletet [The Cartel Court annuls a judgement by an arbitral tribunal]. A kartel 1933, 2:5.

A Kartelbíróság újabb ítélete. [The Cartel Court's new ruling] (1933). A Kartel 3:1.

A szénkartel vesszőfutása a kartelbíróság előtt, [The Ordeal of the Coal Cartel in Front of the Cartel Court] Pesti Napló, 21 December 1932.

Bacsó, J. (1917). A polgári perrendtartás tankönyve [Textbook on the civil trial process]. Budapest: Grill Károly.

Dobrovics, K. (1933). A karteltörvény befolyása a magánjogi jogviszonyokra [The influence of the Act on cartels on legal relations in private law]. Közgazdasági Értesitö 28:10.

Egy elvi jelentőségü ítélet, [A Principled Decision] Pesti Napló, 18 August 1932.

Falcsik, D. (1908). A polgári perjog tankönyve [Textbook of Hungarian civil procedure law]. Budapest.

Gaár, V. (1911). A magyar polgári perrendtartás (1911. évi I. t.-cz.) Magyarázata [Explanation of the Hungarian civil trial process (Act I of 1911)]. Budapest.

\footnotetext{
${ }^{24}$ P. IV 5261/1932. In: GDt. vol. XXVI, p. 741. Co-defendants had to pay the litigation costs according to Section 9 of Act XX of 1931. and Section 425. of Act I. of 1911.

${ }^{25}$ Ibid. at 18.
} 
Harasztosi K. F. (1936). A kartel [The Cartel]. Budapest: Grill Károly Könyvkiadóvállalata.

Kamarai választott bíróság bírája nem kamara köteles perében [An arbitrator on the chamber's arbitral tribunal in a trial not required by the chamber]. Közgazdasági Értesitö (30), 1935/8.

Kelemen, S. (1933). Választottbíróságok és a karteltörvényünk [Arbitral tribunals and the Hungarian Act on cartels]. A kartel 2:3.

Köházi, E. (1934). Karteljogi bírói gyakorlat, [The Leading Cases of the Cartel Law] Közgazdasági Értesitö, 29:15.

Kovács, M. (1930). A polgári perrendtartás magyarázata [The explanation of the Code of Civil Procedure], Budapest.

Magyary, G. (n.d.). Magyar polgári perjog [Hungarian civil trial law]. Budapest.

Meszlény, A. (1911). Bevezetö a polgári perrendtartáshoz [Introduction to the civil trial process]. Budapest: Atheneum.

Nizsalovszky, E., Petrovay, Z., Térfy, B. \& L. Zehery (1932-1933). Grill-féle Uj Döntvénytár, [The Grill's New Case-book] vol. XXV, Budapst. Károly Könyvkiadóvállalata.

Ranschburg, N. (1931). Karteljog, Kartelszervezet [Cartel law, cartel organization]. A gazdasági versenyt szabályozó megállapodásokról szóló 1931. évi XX-ik törvénycikk magyarázatával és végrehajtási rendeletekkel. Budapest: Iparjogvédelmi Egyesület..

Róth, S. (1901). Választott és tőzsdebíróság [Arbitral tribunal and stock exchange tribunal]. Jogtudományi Közlöny 36:25.

Szabó, I. (2016). A kartellfelügyelet szervezete és hatásköre az 1931. XX. törvénycikk nyomán [The organisation and jurisdiction of the cartel supervisory agency pursuant to Act XX of 1931] in Versenytükör 12:Különszám. 'A kartellfelügyelet szervezete és hatásköre az 1931. XX. törvénycikk nyomán [The organisation and jurisdiction of the cartel supervisory agency pursuant to Act XX of 1931] [n Versenytükör: a Gazdasági Versenyhivatal Versenykultúra Központjának lapja 12:64-83.

Szentpáli G. L. (1932). A karteltörvény alkalmazásának premierje [The first application of the Act on cartels]. A kartel 2:2.

Zoltán, Ö. (1986). „A nemzetközi választott bíráskodás egyes kérdéseiről” [On certain questions of international arbitral adjudication]. Jogtudományi Közlöny 41:467-472. 